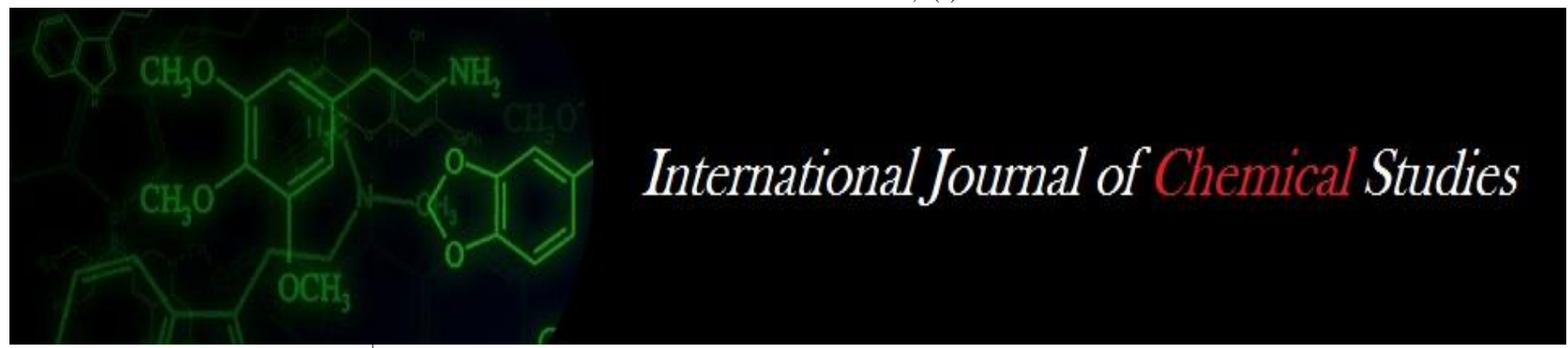

P-ISSN: 2349-8528

E-ISSN: 2321-4902

www.chemijournal.com

IJCS 2020; 8(4): 1786-1789

(C) 2020 IJCS

Received: 18-05-2020

Accepted: 19-06-2020

\section{B Venkateswarlu}

Department of Plant Pathology, Odisha University of Agriculture and Technology, Bhubaneswar, Odisha, India

\section{Beura SK}

Department of Plant Pathology, Odisha University of Agriculture and Technology, Bhubaneswar, Odisha, India

\section{Corresponding Author:}

Beura SK

Department of Plant Pathology, Odisha University of Agriculture and Technology, Bhubaneswar, Odisha, India

\section{Studies on fungicides against Rhizoctonia solani f.sp. Sasakii causing banded leaf and sheath blight of maize}

\section{B Venkateswarlu and Beura SK}

DOI: https://doi.org/10.22271/chemi.2020.v8.i4r.9888

\begin{abstract}
Eight fungicides namely: Thiophenate-Methyl, Validamycin, Propineb, Difenoconazole, Carbendazim + Mancozeb, Carbendazim, Mancozeb and Hexaconazole were screened in-vitro by using poisoned food technique for their effect on inhibition of mycelium growth of Rhizoctonia solani $\mathrm{f}$.sp. sasakii, the causal agent of banded leaf and sheath blight of maize. Among all fungicides screened, maximum inhibition of mycelium growth was observed in Difenoconazole, Thiophenate-Methyl and Hexaconazole, while maximum Percent disease reduction was observed in Validamycin followed by Difenoconazole. Maximum grain yield was recorded in Validamycin and Difenoconazole among the tested all fungicides.
\end{abstract}

Keywords: Rhizoctonia solani f.sp. Sasakii, Fungicides, in-vitro, mycelial growth, in-vivo

\section{Introduction}

Maize (Zea mays L.) is one of the oldest cereals which have been under cultivation for thousands of years. It is a miracle $\mathrm{C} 4$ crop and yellow revolution is to be brought by this crop. Globally, maize is known as 'queen of cereals' because it has the highest genetic yield potentiality among the cereals. It was introduced to India by Portuguese at about the beginning of the $17^{\text {th }}$ century (CMIE, 2019) ${ }^{[2]}$. Maize ranks first in world production (960 million tons from 177 million hectares) followed by wheat (691 million tons) and rice (461 million tons). In India, maize contributes nearly $9 \%$ in the national food basket and more than Rs.100 billion to the agricultural GDP at current prices apart from the generating employment to over 100 million man-days at the farm and downstream agricultural and industrial sectors. In Odisha, it is grown in many districts like Nabarangpur, Koraput, Kalahandi, Mayurbhanj, Keonjhar, Jajpur and others. It covers an area of $0.28 \mathrm{~m}$ ha from which it produces $0.8 \mathrm{~m} \mathrm{t}$ at a productivity level of $2.8 \mathrm{t} \mathrm{ha}^{-1}$ (Department of Agriculture, Odisha 2013-14 and Directorate of Economics and Statistics, 2013) ${ }^{[4,5]}$.

Around 112 diseases of maize have been reported so far from different parts of the world. Of these, 65 are known to occur in India leading to about $15-20 \%$ yield losses annually ${ }^{[8]}$. Among them Banded leaf and sheath blight (BLSB) of maize caused by Rhizoctonia solani $\mathrm{f}$. sp. sasakii Exner is gaining economic importance in Odisha. Several fungicides like carbendazim, Thiophanate-methyl, propineb, validamycin, mancozeb +carbendazim, mancozeb, difenoconazole and hexaconazole are found to be effective in inhibiting the growth of pathogen in in-vitro condition (Sharma, R.C. and Rai, S.N. 1999) ${ }^{[13]}$. Some chemicals like carbendazim and Thiophanate-methyl also proved most effective as they caused the maximum inhibition of mycelial growth (Kumar V. and Jha M.M, 2000) ${ }^{[17]}$. Yet, limited information is available on its sustainable management. Therefore, the present investigation was aimed to study inhibition of mycelia growth of $R$. solani f. sp. sasakii at different concentrations of several fungicides. In view of the increasing importance of BLSB disease, the present study was carried out. The purpose of the study was to evaluate different fungicides under laboratory conditions to find out the most effective one for final use. The results of this study will be helpful to the maize growers to adopt the most appropriate control strategy.

\section{Materials and Methods}

The present investigation was carried out at Department of Plant Pathology, College of Agriculture, Odisha University of Agriculture and Technology, Bhubaneswar, Odisha, India during year 2015-16. 


\section{Isolation of the pathogen}

Isolation of the pathogen The diseased leaves and leaf sheaths of maize plants showing characteristic symptoms of banded leaf and sheath blight were collected from Umerkote Odisha during the year 2015-16. Infected portion of collected leaves and leaf sheaths were cut into small pieces of 5 to $6 \mathrm{~mm}$ and the bits. For 1 minute, they were surface sterilized with 1.0 per cent sodium hypochlorite solution. Consequently, they were washed three times with double distilled sterilized water, and then aseptically transferred to sterilized Petri plates containing sterilized PDA medium in aseptic condition. These plates were incubated at $27 \pm 1{ }^{\circ} \mathrm{C}$ for four days to obtain luxuriant growth of the fungus. Purification of isolated fungi was done using hyphal tip technique. The principle growth characters like morphological, cultural and sclerotia formation were considered for identification of pure cultures of causal organism. These characters were compared and identified as $R$. solani f. sp. sasakii based on the observed traits (Sharma and Saxena 2002) ${ }^{[14]}$. The pure culture of the fungus was sub cultured on PDA slants and kept in laboratory at $27 \pm 2{ }^{\circ} \mathrm{C}$ for 15 days. In refrigerator, at $5{ }^{\circ} \mathrm{C}$ such mother culture slants were preserved. Further, these cultures were sub-cultured once in a month and used for future studies.

\section{Efficacy of fungicides}

Poison food technique was followed to test the efficacy of the fungicides

The experiments conducted in Completely Randomized Design (CRD) with 9 treatments and 3 replications at Department of Plant Pathology, Collage of Agriculture, OUAT, Bhubanswar.

The pathogen Rhizoctonia solani f.sp. sasakii was grown on PDA medium in Petri plates for four days prior to experiment. Fungicide suspension was prepared in PDA by adding requisite quantities of fungicides to obtain the desired concentration on the basis of active ingredient of the chemical. Sterilized Petri plates were filled with such kind of Poisoned medium. PDA medium was poured in each of the sterilized Petri plates. Mycelial disc of $5 \mathrm{~mm}$ was taken from the periphery of four days old culture and placed in the centre and incubated at $28 \pm 2^{\circ} \mathrm{C}$ till growth of the fungus reaches the periphery in the control plate. Three replications were maintained for each treatment. Average of colony diameter was measured in two directions and inhibition percentage was calculated with formula (Vincent, 1947) ${ }^{[19]}$.

$\mathrm{I}=100(\mathrm{C}-\mathrm{T}) / \mathrm{C}$

Where, $\mathrm{I}=$ Per cent inhibition of mycelium growth

$\mathrm{C}=$ Growth of mycelium in control

$\mathrm{T}=$ Growth of mycelium in treatment

\section{Treatment details}

Eight fungicides viz., thiophenate-M $70 \mathrm{WP}$, validamycin 3 SL, propineb $70 \mathrm{WP}$, difenoconazole $25 \mathrm{EC}$, carbendazim
$12 \%+$ mancozeb $63 \%$, carbendazim $50 \mathrm{WP}$, mancozeb $75 \mathrm{WP}$ and hexaconazole $5 \mathrm{EC}$ were evaluated in vitro at $0.05,0.10$, $0.150 .20,0.25$ and 0.30 per cent concentration.

\section{Evaluation of Fungicides}

In vitro screening of fungicides reveal the efficacy of various fungicides and provide firsthand information confirming fungi toxicity against specific pathogen and therefore it serves as a reliable basis for field testing validamycin, difenoconazole and hexaconazole are found to be effective in inhibiting the growth of pathogen in in vitro condition. Under field condition also, all the fungicides except mancozeb were effective in reduce severity (Ahuja and Payak, 1986; Puzari et al., 1998, Pandey, 1992 and Sharma and Rai, 1999) ${ }^{[11,9,13] .}$

Field experiment was conducted during kharif season 2016 at Central Agricultural Research Farm, Bhubaneswar farm, Bhubaneswar in a Randomized block design with three replications to assess the possibility of managing disease by different eight fungicides. Seeds of moderate susceptible maize hybrid Vivek Hybrid- 43 were sown Foliar spray with eight fungicides, viz. thiophenate-M $70 \mathrm{WP}$, validamycin 3 SL, propineb $70 \mathrm{WP}$, difenoconazole $25 \mathrm{EC}$, carbendazim $12 \%+$ mancozeb $63 \%$, carbendazim $50 \mathrm{WP}$, mancozeb $75 \mathrm{WP}$ and hexaconazole 5 EC $50 \%(1 \mathrm{ml} / \mathrm{l})$ were given 30 and 40 days after sowing. The field trail was conducted under irrigated, sandy red loam soil conditions. Hybrid Vivek Hybrid-43 was sown on 10 June 2016 in a plot size $3 \mathrm{~m} \times 3 \mathrm{~m}$ with spacing of $60 \mathrm{~cm} \times 20 \mathrm{~cm}$ in 6 rows.

Recommended dose of fertilizers and insect control measures were followed as per the package and cultural practice of ACRIP, Maize, OUAT, Bhubaneswar. Culture of $R$. solani $\mathrm{f}$. sp. sasakii was multiplied on autoclaved barley grains and artificially inoculated on untreated plots. Inoculations were made by inserting 2-3 maize grains covered with fungal growth of pathogen isolates gently between the rind and the leaf sheath of plants. High humidity was maintained during disease development by frequent watering and irrigation by sprinkler (Singh, 1998 and (Sharma and Saxena, 2002) ${ }^{[14]}$.

The observations on disease severity were recorded using at silk drying stage using 1-5 scale (Ahuja and Payak, 1983) ${ }^{[1]}$. The per cent disease index (PDI) and per cent efficacy of disease control (PEDC) over the control were calculated by using the following formula (Wheeler, 1969) ${ }^{[18]}$.

On the basis of 100-seed weight, grain and stover yield and per cent increase in grain and stover yield was calculated. The percentage data were angularly transformed prior to statistical analysis and all data subjected to analysis of variance using spilt plot design (Hoshamand, 2006) ${ }^{[7]}$.

\section{Results}

There were statistically significant differences among all the treatments for PDI. The PDI significantly differed by different chemicals in vitro (Table 1).

Table 1: Effect of fungicides against R solani caused by BLSB on maize

\begin{tabular}{|c|c|c|c|c|c|c|c|c|c|}
\hline S. No & Fungicide & \multicolumn{4}{|c|}{ Radial growth in (mm) at concentrations } & Mean & Inhibition (\%) \\
\hline & & 0.05 & 0.10 & 0.15 & 0.2 & 0.25 & 0.30 & & \\
\hline 1 & thiophenate-M 70 WP & $1.1(6.0)^{*}$ & $0.3(3.1)$ & $0.2(2.6)$ & $0.1(1.8)$ & $0.05(1.3)$ & $0.04(1.1)$ & $0.2(2.6)$ & 99.96 \\
\hline 2 & validamycin 3 SL & $0.9(5.4)$ & $0.8(5.1)$ & $0.5(4.1)$ & $0.3(3.1)$ & $0.2(2.6)$ & $0.1(1.8)$ & $0.4(3.6)$ & 99.90 \\
\hline 3 & propineb 70 WP & $20.4(26.9)$ & $15.2(22.9)$ & $5.2(13.2)$ & $1.9(7.9)$ & $1.5(7.0)$ & $1.0(5.7)$ & $7.3(13.9)$ & 99.00 \\
\hline 4 & difenoconazole 25 EC & $0.7(4.8)$ & $0.3(3.1)$ & $0.2(2.6)$ & $0.1(1.8)$ & $0.05(1.3)$ & $0.02(0.8)$ & $0.2(2.4)$ & 99.98 \\
\hline 5 & carbendazim 12\%+ mancozeb 63\% & $12.1(20.4)$ & $9.2(17.7)$ & $7.1(15.5)$ & $5.3(13.3) 3.2(10.3)$ & $2.1(8.3)$ & $6.1(14.2)$ & 97.90 \\
\hline 6 & carbendazim 50 WP & $5.3(13.3)$ & $2.2(8.5)$ & $2.1(8.3)$ & $2.05(8.2)$ & $2.0(8.1)$ & $2.0(8.1)$ & $2.2(9.0)$ & 98.00 \\
\hline 7 & mancozeb 75 WP & $20.2(26.7)$ & $15.3(23.0)$ & $10.1(18.5)$ & $5.2(13.2)$ & $2.9(9.8)$ & $2.0(8.1)$ & $8.9(16.5)$ & 98.00 \\
\hline 8 & hexaconazole 5 EC & $1.8(7.7)$ & $0.9(5.4)$ & $0.4(3.6)$ & $0.1(1.8)$ & $0.05(1.3)$ & $0.04(1.1)$ & $0.5(3.9)$ & 99.96 \\
\hline
\end{tabular}




\begin{tabular}{|c|c|c|c|c|c|c|c|c|c|}
\hline 9 & Control (No fungicide) & $85(67.2)$ & $75(60.0)$ & $86(68.0)$ & $90(71.6)$ & 87 (68.9) & $79(62.7)$ & $70.5(66.4)$ & - \\
\hline & $\mathrm{SE}(\mathrm{m}) \pm$ & & & & & & & 1.89 & \\
\hline & $\mathrm{CD}(0.05)$ & & & & & & & 5.40 & \\
\hline
\end{tabular}

*Angular transformed values

Among the eight fungicides tested, validamycin at $0.2 \%$, difenoconazole $0.1 \%$ and hexaconazole $0.2 \%$ recorded maximum mean mycelia inhibition which were significantly superior to all other treatments followed by carbendazim+ mancozeb $0.3 \%$, thiophenate methyl $0.1 \%$, propineb $0.2 \%$ and mancozeb $0.3 \%$ in media tests in the laboratory.

Results revealed that all the tested fungicides significantly inhibited mycelial growth of the fungus. Among the eight fungicides tested, difenoconazole $25 \%$ EC, (99.98\%), thiophenate methyl M-70\% WP, hexaconazole 5\% EC (99.96\%) and validamycin 3\% SL (99.90) propineb 70\% WP (99.00\%) gave maximum mean mycelial inhibition which were significantly superior to all other treatments followed by carbendazim (98.0\%) and mancozeb 75\% WP (98.00\%). At $0.3 \%$ concentration, difenoconazole $25 \%$ EC (99.98\%), thiophenate methyl M-70\% WP and hexaconazole 5\% EC (99.96\% and $99.96 \%$ mycelial inhibition respectively) were statistically on a par with each other as well as significantly superior over remaining fungicides followed by validamycin $3 \%$ SL (99.90) propineb 70\% WP (99.00\%) against $R$. solani f. sp. sasakii under in-vitro conditions (Jones R. K., Belmar S.B. and Jeger M.J 1986). Carbendazim also inhibited $98 \%$ of fungal growth of $R$. solani (Chahal K.K.S. Sokhi S.S. and Rattan G.S. 2003) ${ }^{[3]}$, (Gupta R.P 2002) ${ }^{[6]}$ (Tiwari R.K.S., Chandravanshi S.S., Ojha B. and Thakur B.S. 2002) ${ }^{[17]}$.

Table 2: Effect of fungicides on per cent disease index of banded leaf and sheath blight

\begin{tabular}{|c|c|c|c|c|}
\hline S. No & Fungicide & Dosage & PDI (\%) & Inhibition (\%) \\
\hline 1 & Thiophenate-M 70 WP & 0.1 & 15.0 & 83.1 \\
\hline 2 & Validamycin 3 SL & 0.2 & 7.0 & 92.1 \\
\hline 3 & Propineb 70 WP & 0.2 & 45.0 & 49.4 \\
\hline 4 & Difenoconazole 25 EC & 0.1 & 8.0 & 91.0 \\
\hline 5 & Carbendazim 12\%+ mancozeb 63\% & 0.3 & 29.0 & 67.4 \\
\hline 6 & Carbendazim 50 WP & 0.1 & 39.0 & 56.1 \\
\hline 7 & Mancozeb 75 WP & 0.3 & 41.0 & 53.9 \\
\hline 8 & Hexaconazole 5 EC & 0.2 & 8.9 & 89.8 \\
\hline 9 & Control (No fungicide) & - & 89.0 & - \\
\hline
\end{tabular}

Table-2 In-vivo evaluation of fungicides against Rhizoctonia solani f. sp. sasakii Fungicide Per cent disease reduction was calculated

There were statistically significant differences among all the treatments for PDI. The PDI significantly differed by different chemicals tested in vitro and foliar application of chemicals (Tables 2 and 3).

Maximum per cent disease incidence was recorded in control
(89.0\%) followed by propineb (45.0\%), mancozeb (41.0\%), carbendazim (39.0\%) (Sinha, 1992) ${ }^{[16]}$.

Validamycin has recorded the highest per cent inhibition over control plot $(92.1 \%)$. Similar trend was observed the difenoconazole (91.0\%), hexaconazole (89.8\%), and thiophenate methyl $(83.1 \%)$. Lowest per cent inhibition over control plot was carbendazim +mancozeb (97.4\%) followed by carbendazim (90\%) and Mancozeb (90\%).

Table 3: Bio efficacy of fungicides against (R. solani) on Vivek maize hybrid-43

\begin{tabular}{|c|c|c|c|c|c|c|}
\hline S. No & Fungicide & Dosage & Severity (1-5) & Yield (q/ha) & 1000 grain wt (g) & Cobs/plant \\
\hline 1 & thiophenate-M 70 WP & 0.1 & 2.0 & 21.6 & 178.0 & 0.9 \\
\hline 2 & validamycin 3 SL & 0.2 & 1.0 & 30.0 & 188.0 & 1.0 \\
\hline 3 & propineb 70 WP & 0.2 & 4.0 & 18.6 & 179.0 & 0.9 \\
\hline 4 & difenoconazole 25 EC & 0.1 & 1.0 & 25.2 & 208.0 & \\
\hline 5 & carbendazim 12\%+ mancozeb 63\% & 0.3 & 3.0 & 21.4 & 183.0 & \\
\hline 6 & carbendazim 50 WP & 0.1 & 4.0 & 18.5 & 183.0 & 0,9 \\
\hline 7 & mancozeb 75 WP & 0.3 & 4.0 & 22.0 & 183.0 & 0.9 \\
\hline 8 & hexaconazole 5 EC & 0.2 & 2.0 & 22.3 & 185.0 & 0.9 \\
\hline 9 & Control (No fungicide) & - & 5.0 & 17.5 & 174.0 & 1.0 \\
\hline & SE(m)+ & & & 0.23 & 0.08 & 0.9 \\
\hline & CD (0.05) & & & 0.69 & 0.26 & 0.12 \\
\hline
\end{tabular}

Foliar spray differed significantly in grain yield in all fungicides tested. Maximum grain yield was observed in two sprays of validamycin @ $0.1 \%$ at 30 and 40 DAS (30.0 q/ha) over the control $(17.5 \mathrm{q} / \mathrm{ha})$ and was statistically on a par with propineb (18.6 q/ha), carbendazim $18.5 \mathrm{q} / \mathrm{ha}$.

Management of BLSB disease of maize by two sprays of validamycin 3 SL@ $0.2 \% 30$ and 40 DAS recorded the low disease severity, highest grain yield.

\section{Discussion}

In vitro screening of fungicides reveal the efficacy of various fungicides and provide firsthand information confirming fungi toxicity against specific pathogen and therefore it serves as a reliable basis for field testing validamycin, difenoconazole and hexaconazole are found to be effective in inhibiting the growth of pathogen in in vitro condition. Under field condition also, all the fungicides except mancozeb were effective in reduce severity (Ahuja and Payak, 1986; Puzari et al., 1998, Pandey, 1992 and Sharma and Rai, 1999) ${ }^{[11,9,13] .}$

\section{Conclusion}

Among all fungicides screened, maximum inhibition of mycelium growth was observed in Difenoconazole, Thiophenate-Methyl and Hexaconazole, while maximum 
Percent disease reduction was observed in Validamycin followed by Difenoconazole. Maximum grain yield was recorded in Validamycin and Difenoconazole among the tested all fungicides.

\section{References}

1. Ahuja SC, Payak MM. A rating scale for banded leaf and sheath blight of maize. Indian Phytopath. 1983; 36:338340 .

2. Centre for Monitoring Indian Economy (CMIE) reports, 2009. http//www.cmie.com.

3. Chahal KKS, Sokhi SS, Rattan GS. Indian Phytopathology. 2003; 56:22-26.

4. Department of Agriculture, Odisha, 2013-14.

5. Directorate of Economics and Statistics, 2013.

6. Gupta RP. Journal of Mycology and Plant Pathology. 2002; 32:141.

7. Hoshmand R. Design of Experiment for Agriculture and Natural Sciences, 2006, 135.

8. Chapman and Hall Publication Pvt Ltd., USA.

9. Pandey MK. Studies on banded leaf and sheath blight of maize M.Sc. thesis, G.B. Pant University of Agriculture and Technology, Pantnagar, 1992, 79.

10. Payak MM, Renfro BL. Combating maize diseases. Indian Farmer Dig. 1968; 1:53-58.

11. Puzari KC, Saikia UN, Bhattacharya A. Management of banded leaf and sheath blight of maize with chemicals. Indian Phytopath. 1998; 51:78-80.

12. Saxena SC. Bio intensive integrated disease management of banded leaf and sheath blight of maize. Asian Regional Maize Workshop, Bangkok, Thailand, 2002, 58.

13. Sharma RC, Rai SN. Indian Phytopathology. 1999; 52:94-95.

14. Sharma G, Saxena SC. Integrated management of banded leaf \& sheath blight of maize (Zea mays L.) caused by Rhizoctonia solani, (Kuhn). Adv. Plant. Sci. 2002; 15:107-113.

15. Singh AK. 'Studies on Rhizoctonia solani, incitant of banded leaf and sheath blight of maize (Zea mays L.) with special reference to variability and integrated management'. Ph.D. thesis, G.B. Pant University of Agriculture and Technology, Pantnagar, 1998.

16. Sinha PP. Chemical control of banded sclerotial disease of maize. Orissa J Agric. Res. 1992; 5:54-57.

17. Tiwari RKS, Chandravanshi SS, Ojha B, Thakur BS. Journal of Mycology and Plant Pathology. 2002; 32:418.

18. Wheeler BEJ. An Introduction to Plant Disease. John Wiley Sons Limited London, 1969, 301.

19. Vincent JM. Distortion of fungal hyphae in the presence of certain inhibitors, Nature. 1947; 159:850. 